\title{
CONDITION AND DEVELOPMENT OPPORTUNITIES OF BREEDING PIGS IN POLAND
}

\author{
Wojciech Ziętara ${ }^{凶}$ \\ Instytut Ekonomiki Rolnictwa i Gospodarki Żywnościowej - PIB
}

\begin{abstract}
The article presents current status of the pig population in Poland and the reasons for its diminish in recent years. The main cause should be considered decline in the profitability of the production of pork, especially in farms with small-scale production. Dramatic drop in the number of pigs in farms occurred maintaining the herd to 200 units. Development opportunities are devoid farms living to 20 sows or sellers to 400 fattening pigs per year. Development opportunities are farms living 20-50 sows or selling annually 400-1000 pigs or piglets 500-1200. A fully competitive farms are sustained over 50 sows and selling over 1,000 fattening pigs per year, or more than 1,200 piglets. The main factor determining the profitability of the pork production is its scale.
\end{abstract}

Key words: the number of pigs, pig farms, production efficiency, competitiveness

\section{INTRODUCTION}

Production of slaughter pigs in Poland has had a very long history. In the period between WWI and WWII Poland was an important exporter of slaughter pigs to Great Britain (Blicharski and Hammermeister, 2013). In the post-WWII period the production of slaughter pigs played a considerable role. Despite a drastic drop in the pig population in the years 2000-2015, amounting to approx. $41 \%$, the value of commercial production of slaughter pigs increased in that period by $37 \%$. Nevertheless, the share of slaughter pigs in the commercial animal production decreased from $37.6 \%$ in 2000 to
$23.7 \%$ in 2013. It was the result of a greater growth rate in poultry for slaughter and milk production. A negative balance was also observed in foreign trade for pork. In quantitative terms the balance in 2009 was -278 thousand ton, while in 2014 it was -197.3 thousand ton. In value terms the balance in those years was -524.5 million EUR and -446.8 million EUR. Moreover, a marked increase was also observed in the import of live animals from 401.7 thousand head in 2007 to 5449.0 thousand head in 2014. The year 2007 was the last, in which a positive balance of foreign trade in live animals was recorded, amounting to 32.3 thousand head. In turn, the negative balance in 2014 amounted to 5364.4 thousand head. In imports of live animals the predominant share comprised animals of max. $50 \mathrm{~kg}$ (piglets and porkers). Their share was $73 \%$.

A factor having a significant effect on processes occurring in agricultural production, including pig rearing, was connected with trends modifying prices for factors of production and agricultural produce. These trends are presented in Figure 1. It shows that in the analyzed period of 1995-2014 the greatest increase, over 5-fold, was recorded for labour costs in national economy, of which the main component were wages. An increase in labour costs in the national economy outside agriculture had a considerable effect on the subjective perception of the income situation of farmers. In the same period costs (prices) of factors of production in agriculture purchased by farmers increased over 3-fold, while prices of agricultural products sold by farmers increased over

$\bowtie$ prof. dr hab. Wojciech Ziętara, Instytut Ekonomiki Rolnictwa i Gospodarki Żywnościowej - Państwowy Instytut Badawczy, ul. Świętokrzyska 20, 00-002 Warszawa, Poland, e-mail: zietara@ierigz.waw.pl 


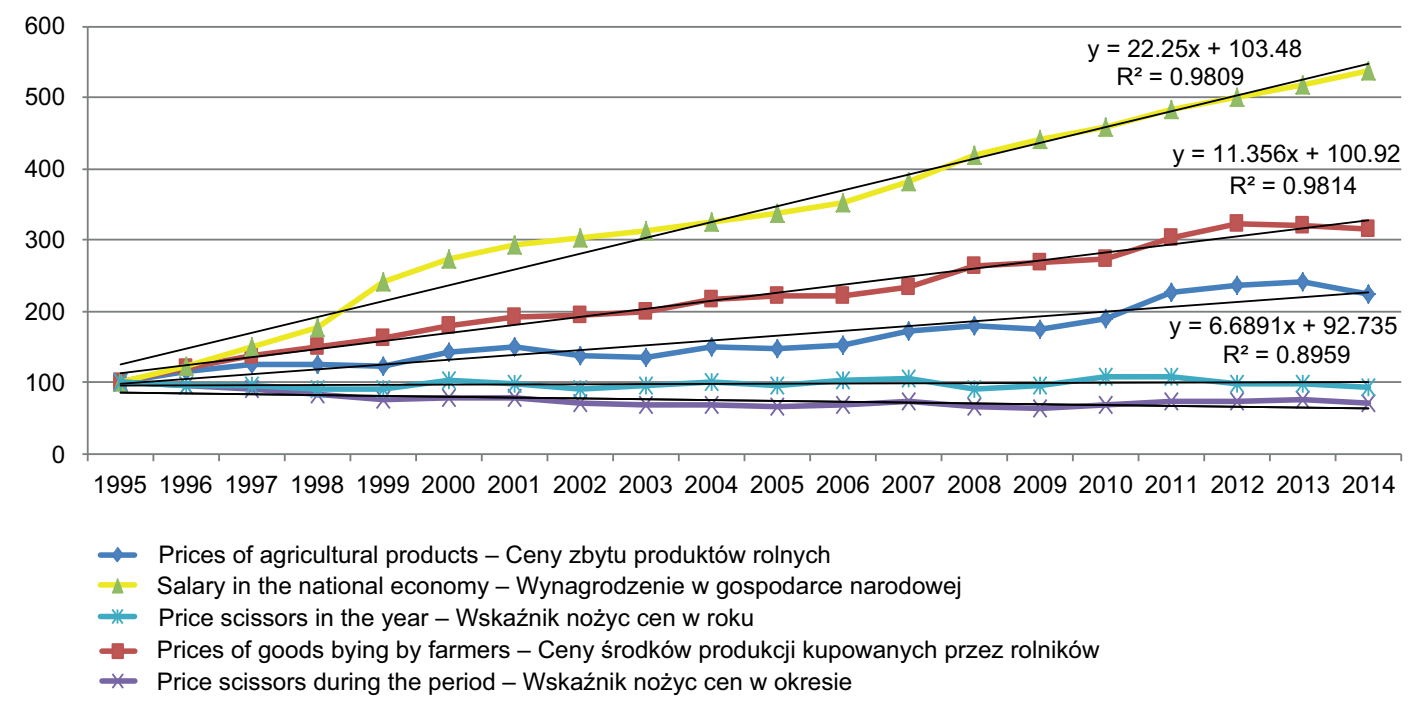

Fig. 1. Trends in costs of factors of production and prices of agricultural products Source: GUS (2014, 2015a, 2015b).

Rys. 1. Tendencje zmian w kosztach czynników produkcji i cen produktów rolnych Źródło: GUS (2014, 2015a, 2015b).

2 -fold. The differing growth rates for prices of factors of production and prices of agricultural produce resulted in a reduction of the price scissors index in the analyzed period to $70 \%$.

This means that the growth rate for prices of production factors purchased by farmers was by $30 \%$ higher than that of prices for agricultural products. As a result of these trends the unit profitability of agricultural production decreased. In such a situation farmers in an attempt to obtain a satisfactory income (parity) ${ }^{1}$ have to increase the economic efficiency of labour ${ }^{2}$. It may be achieved by increasing the scale of production and in animal farms - by increasing the scale of animal rearing (number of head).

These adverse trends in pig rearing justify the need to undertake studies in order to determine causes for the current situation and indicate the potential and directions to reverse these undesirable trends.

\footnotetext{
${ }^{1}$ Parity in income - family farm income per unit unpaid labour (FWU) corresponding to the level of wages of employees in the national economy outside agriculture.

${ }^{2}$ Economic efficiency of labour - the value of generated agricultural production per unit labour outlays (AWU Annual Work Unit).
}

\section{AIM OF THE STUDY, SOURCES AND METHODS}

The aim of this study was to assess the productive and economic activity of farms specialising in the production of slaughter pigs in Poland and to determine their efficiency in comparison to analogous farms from selected EU countries, as well as establish their potential for development. The primary sources of experimental materials comprised statistical data and data from pig farms covered by the Polish and European FADN systems in the years 2009-2013. The study was conducted using the descriptive and comparative methods.

In order to specify the objective of the study the following research hypothesis was adopted: "The scale of production is the primary factor determining efficiency of production of slaughter pigs". The other factors, such as production technology, breeding material, veterinary assistance, etc. are closely related with the scale of production.

In order to determine the competitiveness of farms the competitiveness index $(W k)$ was adopted after Kleinhanss (2015).

The competitiveness index was established as a quotient of income from a farm and the total estimate of costs 
of use of owned factors of production: unpaid labour, land and capital (equation 1$)^{3}$. The value of the competitiveness index $W k \geq 1$ indicates complete coverage of costs of owned factors of production by income, while $W k<1$ indicates incomplete coverage of these costs by income. It was assumed after Kleinhanss to distinguish further classification of $W k$ into the following classes: $W k(-)$ - in the case of negative $\operatorname{Dzgr}(W k 1), 0<W k<1$ - partial coverage of costs of owned factors of production (Wk2), $1=W k<2$ - full coverage of costs of owned factors of production ( $W k 3), W k \geq 2-2$-fold and greater coverage of costs of owned factors of production $(W k 4)$. The competitiveness index $W k 4$ indicates complete competitiveness of a farm. This statement is consistent with an opinion of Biswanger (2011), who stated that an enterprise capable of development should reach the rate of return two-fold greater than lending rate.

$$
W k=\frac{D z g r}{K w z+K w p+K w k}
$$

where:

$W k$ - competitiveness index

$D z g r$ - income from a farm

$K w z$ - opportunity cost of owned land

$K w p$ - opportunity cost of unpaid labour

$K w k$ - opportunity cost of owned capital (without owned land).

In this study competitiveness was defined as the ability of farm to develop. Such a capacity is achieved by a farm when income from the farm covers two-fold costs of owned factors of production. This is a different approach from that in the traditional definition of competitiveness as gaining an advantage (cost, price, quality, etc.) in relation to the competition. The authors (Ziętara and Zieliński, 2012) earlier defined competitive capacity of farms using the category of income from management, which corresponds to the category of "income of an entrepreneur"'s They assumed that competi-

${ }^{3}$ Cost of unpaid labour of the farmer and his family is determined based on the cost of hired labour in analogous classes of economic size of farms. Cost of using owned land was determined at the level of rent in individual classes of economic size. Costs of owned capital were assumed at the level of interest on long-term government-issued bonds.

${ }^{4}$ Income of an entrepreneur was calculated as a difference between income from a farm and opportunity costs of owned factors of production (labour, land and capital). tiveness of a farm is determined by the income obtained by the entrepreneur. The competitiveness index makes it possible to determine various degrees of competitiveness. A doubt arose whether the currently used approach is appropriate. Farms in many countries do not compete directly on the EU and world markets. Trade companies compete on those markets. For this reason the definition of competitiveness of farms as the capacity to develop under market conditions in a given country seems justified.

\section{POSITION AND ROLE OF PRODUCTION OF SLAUGHTER PIGS IN POLAND}

Within the last 10-20 years agricultural production has been growing, particularly after Poland's accession to the EU. In the years 2000-2014 commercial agricultural production increased by $131 \%$ (Table 1). Its structure also changed. To a greater extent plant production increased at the expense of animal production, which increased in that period by $117 \%$. In animal production the share of production of slaughter pigs was considerable, which in 2000 was $37.6 \%$. In the successive years, despite the quantitative increase, its share decreased to $23.7 \% \mathrm{w} 2014$. In that period production and the share of poultry for slaughter increased from $11.4 \%$ in 2000 to $23 \%$ in 2014 .

Total balance of foreign trade in the last 10-20 years was negative, while in foreign trade in agri-food products in the years 2009-2014 it was positive, whereas the share of live animals and meat in exports of these products in 2014 was approx. 21\% (Table 2). Despite the positive development of foreign trade in agri-food products in the case of trade in pork and live animals the balance was negative, both quantitatively and in terms of value. A particularly disturbing finding was the negative balance in foreign trade in live animals. The year 2007 was the last year, in which a slight positive balance was recorded, amounting to 32.3 thousand head. From 2008 the negative balance increased from 710 thousand head to 5364 thousand head in 2014 . Over $70 \%$ of imports were piglets and porkers, mainly from Denmark, Holland and Germany. This situation has to be seen as highly disturbing. 
Ziętara, W. (2016). Condition and development opportunities of breeding pigs in Poland. J. Agribus. Rural Dev., 4(42), 687-701. DOI: 10.17306/JARD.2016.95

Table 1. Structure of commercial agricultural production in 2000-2014 in Poland

Tabela 1. Struktura towarowej produkcji rolniczej w latach 2000-2014 w Polsce

\begin{tabular}{|c|c|c|c|c|c|c|}
\hline \multirow{2}{*}{$\begin{array}{c}\text { Specification } \\
\text { Wyszczególnienie }\end{array}$} & \multicolumn{2}{|c|}{2000} & \multicolumn{2}{|c|}{2005} & \multicolumn{2}{|c|}{2014} \\
\hline & $\begin{array}{l}\mathrm{mln} \text { PLN } \\
\mathrm{mln} \mathrm{z} 1\end{array}$ & $\%$ & $\begin{array}{l}\mathrm{mln} \text { PLN } \\
\mathrm{mln} \mathrm{z}\end{array}$ & $\%$ & $\begin{array}{l}\mathrm{m} \ln \text { PLN } \\
\mathrm{mln} \mathrm{z}\end{array}$ & $\%$ \\
\hline $\begin{array}{l}\text { Agricultural market output } \\
\text { Towarowa produkcja rolnicza }\end{array}$ & 33491.4 & 100.0 & 42907.0 & 100.0 & 77504 & 100.0 \\
\hline $\begin{array}{l}\text { Index of changes }(2000=100) \\
\text { Wskaźnik zmian }(2000=100) \\
\text { including - w tym: }\end{array}$ & 100.0 & & 128.1 & & 231.4 & \\
\hline $\begin{array}{l}\text { Animal production } \\
\text { Production zwierzęca }\end{array}$ & 20950.4 & 62.6 & 26301.4 & 61.3 & 45490.0 & 58.7 \\
\hline $\begin{array}{l}\text { Index of changes }(2000=100) \\
\text { Wskaźnik zmian }(2000=100) \\
\quad \text { including }-\mathrm{w} \text { tym: }\end{array}$ & 100.0 & & 125.5 & & 217.1 & \\
\hline $\begin{array}{l}\text { Production of slaughter pigs } \\
\text { Produkcja żywca trzodowego }\end{array}$ & 7885.7 & 23.5 & 8340.4 & 19.4 & 10807.0 & 13.9 \\
\hline $\begin{array}{l}\text { Index of changes }(2000=100) \\
\text { Wskaźnik changes }(2000=100)\end{array}$ & 100.0 & $37.6 \mathrm{a}$ & 105.6 & $31.7 \mathrm{a}$ & 137.0 & $23.7 \mathrm{a}$ \\
\hline $\begin{array}{l}\text { Production of poultry for slaughter } \\
\text { Produkcja żywca drobiowego }\end{array}$ & 2400.3 & 7.1 & 4472.5 & 10.4 & 10476.0 & 13.5 \\
\hline $\begin{array}{l}\text { Index of changes }(2000=100) \\
\text { Wskaźnik zmian }(2000=100)\end{array}$ & 100.0 & $11.4 \mathrm{a}$ & 186.3 & $17.0 \mathrm{a}$ & 447.7 & $23.0 \mathrm{a}$ \\
\hline
\end{tabular}

a - share in animal production

Source: GUS, 2014; 2015a, 2015b.

a - udział w produkcji zwierzęcej

Źródło: GUS, 2014; 2015a, 2015b.

Table 2. Foreign trade in pork and live animals

Tabela 2. Handel zagraniczny wieprzowiną i zwierzętami żywymi

\begin{tabular}{|c|c|c|c|c|c|c|}
\hline $\begin{array}{c}\text { Specification } \\
\text { Wyszczególnienie }\end{array}$ & 2009 & 2010 & 2011 & 2012 & 2013 & 2014 \\
\hline $\begin{array}{l}\text { Export (thous. t) equivalent of meat } \\
\text { Eksport (tys. t) w ekwiwalencie mięsa }\end{array}$ & 336.0 & 418.0 & 500.1 & 585.5 & 705.6 & 619.7 \\
\hline $\begin{array}{l}\text { Import (thous. t) } \\
\text { Import (tys. t) }\end{array}$ & 614.0 & 602.0 & 675.2 & 748.7 & 819.0 & 817.0 \\
\hline $\begin{array}{l}\text { Balance (quantity thous. t) } \\
\text { Saldo (ilościowo tys. t) }\end{array}$ & -278.0 & -184.0 & -175.1 & -163.2 & -113.4 & -197.3 \\
\hline $\begin{array}{l}\text { Balance (in value; million EUR) } \\
\text { Saldo (wartościowo; mln euro) }\end{array}$ & -524.5 & -336.0 & -338.7 & -323.9 & -283.4 & -446.8 \\
\hline
\end{tabular}


Table 2 cont. - Tabela 2 cd.

\begin{tabular}{|c|c|c|c|c|c|c|c|c|}
\hline \multicolumn{9}{|c|}{$\begin{array}{l}\text { Handel trzodą chlewną (zwierzętami żywymi w latach 2007-2013; tys. szt.) } \\
\text { Trade in pigs (live animals in 2007-2013; thous. head) }\end{array}$} \\
\hline & 2007 & 2008 & 2009 & 2010 & 2011 & 2012 & 2013 & 2014 \\
\hline $\begin{array}{l}\text { Export } \\
\text { Eksport }\end{array}$ & 434.0 & 418.8 & 442.2 & 274.4 & 102.8 & 138.8 & 107.98 & 84.6 \\
\hline Import & 401.7 & 1124.6 & 1997.5 & 2285.3 & 2667.6 & 3824.3 & 5138.8 & 5449.0 \\
\hline $\begin{array}{l}\text { Balance } \\
\text { Saldo }\end{array}$ & 32.3 & -709.8 & -1155.3 & 2011.1 & -2564.8 & -3685.5 & -5031.0 & -5364.4 \\
\hline
\end{tabular}

Source: GUS (2014, 2015a, 2015b).

Źródło: GUS (2014, 2015a, 2015b).

\section{CHANGES IN PIG POPULATION IN POLAND IN THE YEARS 1993-2015}

During the analyzed period a considerable decrease was recorded in the pig population. In the years 1990-2007 the population of pigs was stable amounting to approx. 18 million head (Fig. 2). Deviations were slight, at approx. $5 \%$. A significant decrease in the population size was observed in 2008 , amounting to $15 \%$ in relation to the previous year. In the successive years the number of head was decreasing further, to 11 million in 2015, which in relation to 2007 was by $39 \%$.
At the same time considerable regional variation was observed, as seen in Figure 3. In 1990 the largest population of pigs was found in the following voivodeships: the Wielkopolskie (17.2\%), Mazowieckie (12.9\%), Kujawsko-pomorskie $(9.3 \%)$, Podlaskie $(7.6 \%)$ and Lubelskie $(7.4 \%)$. Jointly those voivodeships accounted for $54.4 \%$ total pig populations. In the next years significant changes were observed. The regional variation increased. In 2014 five voivodeships (the Wielkopolskie, Kujawsko-pomorskie, Łódzkie, Mazowieckie and the Pomorskie) accounted for $70.7 \%$ pig population. The largest numbers of pigs were reared in the Wielkopolskie $(35.3 \%)$ and

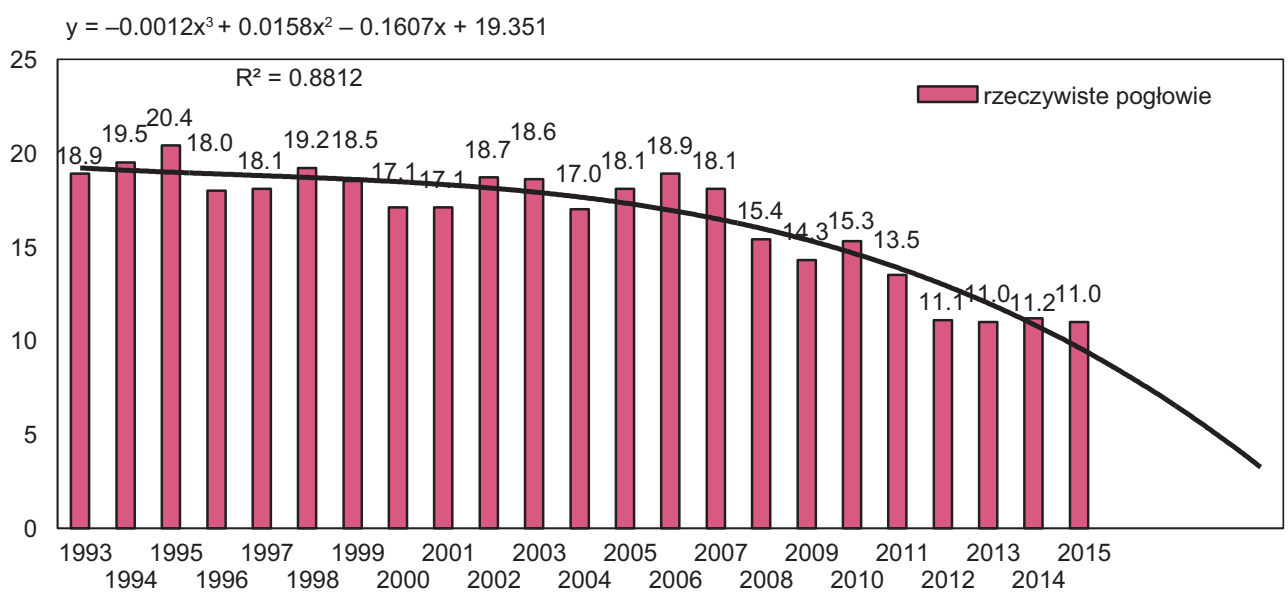

Fig. 2. The number of pigs in Poland in the years 1993-2015

Rys. 2. Pogłowie trzody chlewnej w Polsce w latach 1993-2015 


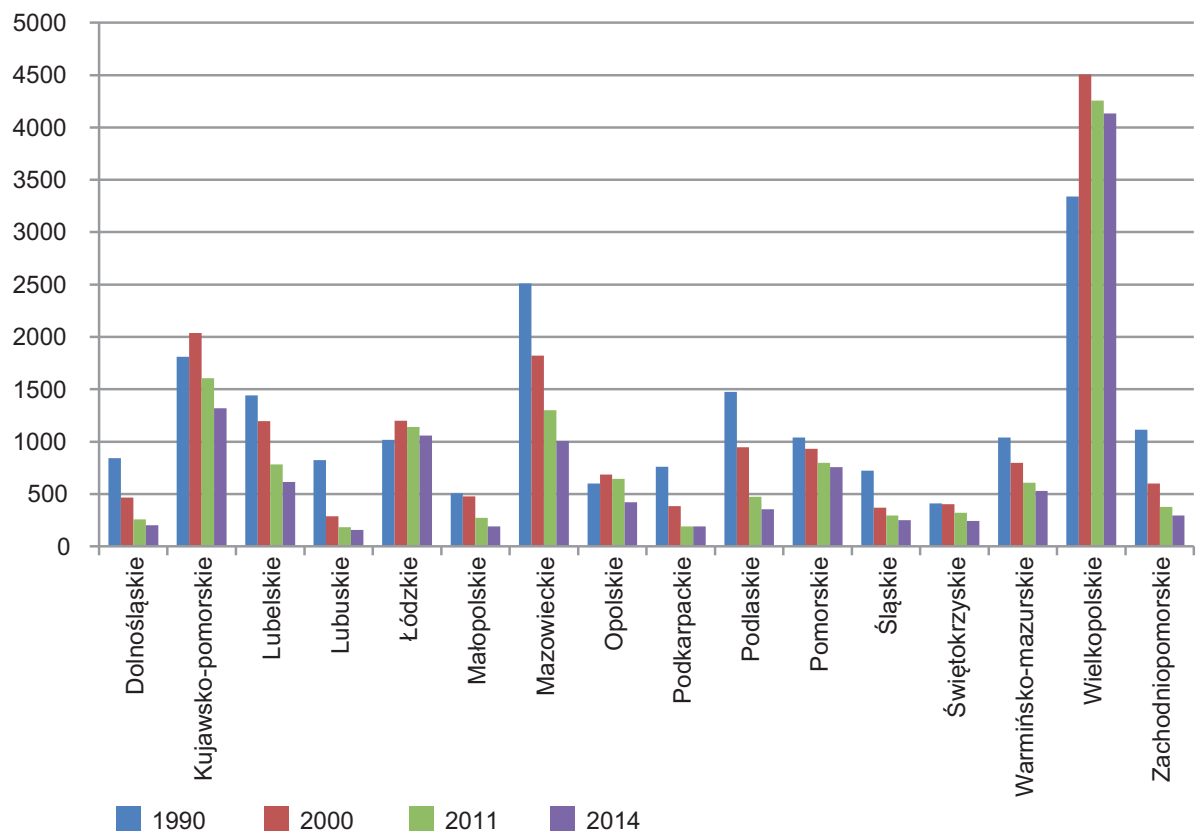

Fig. 3. Changes in pig population in Poland in the years 1990-2014 in the spatial arrangement by voivodeships

Rys. 3. Zmiany w pogłowiu trzody chlewnej w Polsce w latach 1990-2014 w układzie przestrzennym według województw

Kujawsko-pomorskie voivodeships (11.3\%). A drastic drop in the pig population was recorded in the Lubelskie, Małopolskie, Podkarpackie and the Świętokrzyskie voivodeships, in which small farms (max. 5 ha UAA) predominate. The population of pigs also decreased in the Lubuskie and Zachodniopomorskie voivodeships, in which large farms established after restructurisation of state farms predominated and which specialized in plant production.

Changes were also observed in the stocking rate of pigs expressed in the number of head per 100 ha utilised agricultural area (UAA). This is presented in Figure 4. In 1990 the mean stocking in a herd was 103.5 head/ UAA. The highest stocking rate, exceeding the average, was recorded in the Wielkopolskie (163), Pomorskie (146), Kujawsko-pomorskie (142), Lubuskie (119) and the Opolskie voivodeships (112). In 2014 at the decrease in the pig population the variation in stocking rate was greater. The mean stocking rate in that year was $81 \mathrm{head} / 100$ ha UAA. The highest rates were found in the Wielkopolskie voivodeship at 230 head and the $\mathrm{Ku}$ jawsko-pomorskie voivodeship, where it was 124 head.
A high stocking rate was also found in the Łódzkie and the Pomorskie voivodeships, amounting to 110 and 103 head, respectively.

Changes in the population and stocking rates of pigs are closely related with the level of commercial production in agriculture and the scale of production. The Wielkopolskie and the Kujawsko-pomorskie voivodeships are those with the highest commercial scale of agricultural production, including animal production.

A significant factor determining the decrease in the pig production was connected with the scale of production defined by the size of animal herds. In the years 2007-2013 the total population of pigs decreased by $37 \%$ (Table 3). In smaller herds, of max. 200 head, the herd size decreased by $56 \%$, while in herds of min. 200 head the herd size increased by $8.4 \%$. In that herd size class in 2010 in relation to 2007 the increment in herd size was $34.5 \%$. In the successive years it decreased to $12.7 \%$ in 2012 and to $8.4 \%$ in 2013. These numbers indicate the relationship of a decrease in the pig population with the scale of animal rearing. 
Ziętara, W. (2016). Condition and development opportunities of breeding pigs in Poland. J. Agribus. Rural Dev., 4(42), 687-701. DOI: 10.17306/JARD.2016.95

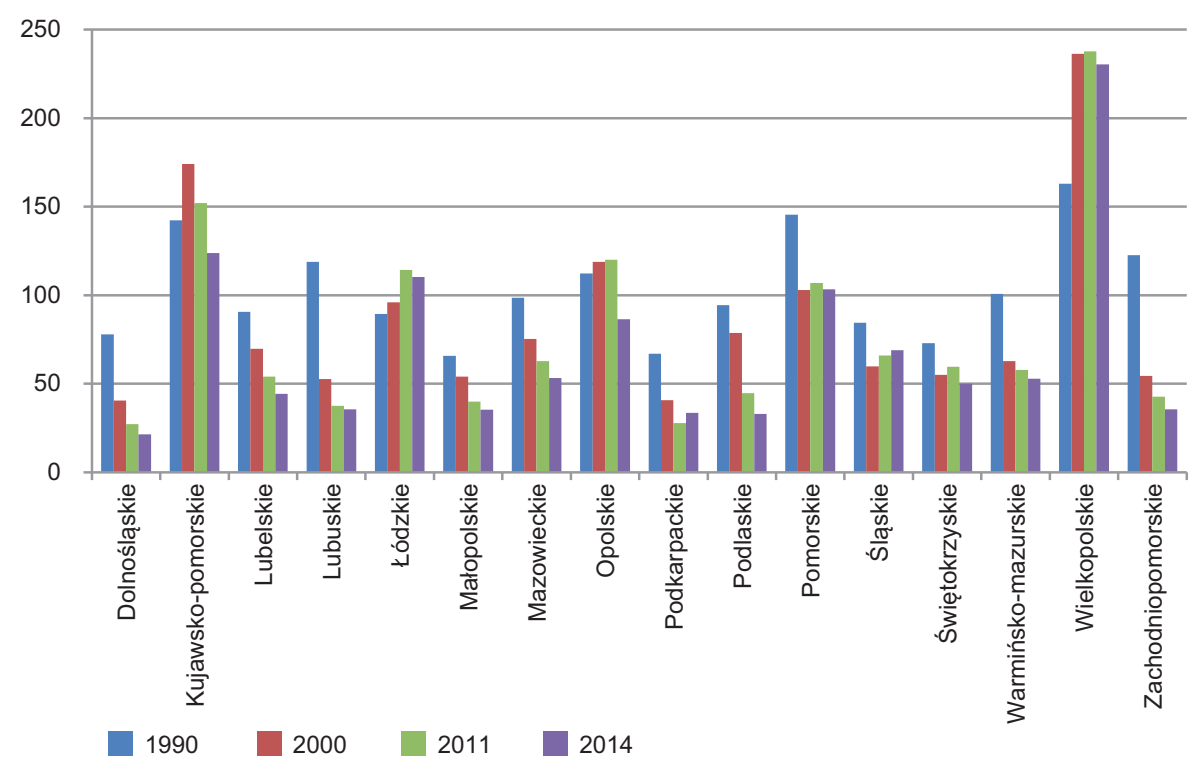

Fig. 4. Changes in stocking rate of pigs in Poland in the years 1990-2014, by voivodeships (pigs/100 ha UAA)

Rys. 4. Zmiany w obsadzie trzody chlewnej w Polsce w latach 1990-2014 w układzie województw (szt./100 ha UR)

Table 3. Changes in the structure of the pig population in Poland in 2007-2013

Tabela 3. Zmiany w strukturze pogłowia trzody chlewnej w Polsce w latach 2007-2013

\begin{tabular}{|c|c|c|c|c|}
\hline $\begin{array}{c}\text { Specification } \\
\text { Wyszczególnienie }\end{array}$ & 2007 & 2010 & 2012 & 2013 \\
\hline $\begin{array}{l}\text { Pig population (thous.) } \\
\text { Pogłowie trzody chlewnej (tys. szt.) }\end{array}$ & 18100.00 & 15278.10 & 11581.32 & 11401.80 \\
\hline $\begin{array}{l}\text { Pig population in herds of }<50 \text { head } \\
\text { Pogłowie trzody w stadach do } 50 \text { szt. }\end{array}$ & 6208.30 & 3936.47 & 2710.02 & 2674.25 \\
\hline $\begin{array}{l}\text { Pig population in herds of } 50-200 \text { head } \\
\text { Pogłowie trzody w stadach } 50-200 \mathrm{szt} \text {. }\end{array}$ & 6552.20 & 4161.43 & 2849.00 & 2937.23 \\
\hline $\begin{array}{l}\text { Pig population in herds } \geq 200 \text { head } \\
\text { Pogłowie w stadach } \geq 200 \text { szt. }\end{array}$ & 5339.50 & 7180.71 & 6022.30 & 5790.32 \\
\hline $\begin{array}{l}\text { Decrease in population in herds }<200 \text { head } \\
\text { Zmniejszenie pogłowia w stadach }<200 \text { szt. }\end{array}$ & - & -4663.11 & -7201.48 & -7149.02 \\
\hline $\begin{array}{l}\text { Index of reduction }(\%) \\
\text { Wskaźnik zmniejszenia (\%) }\end{array}$ & 100.0 & -36.50 & -56.43 & -56.02 \\
\hline $\begin{array}{l}\text { Increase in population in herds }>200 \text { head } \\
\text { Zwiększenie pogłowia w stadach }>200 \text { szt. }\end{array}$ & - & 1841.21 & 682.8 & 450.82 \\
\hline $\begin{array}{l}\text { Index of increase (\%) } \\
\text { Wskaźnik zwiększenia (\%) }\end{array}$ & 100.0 & 34.50 & 12.78 & 8.44 \\
\hline
\end{tabular}

Source: GUS $(2014,2015 a)$.

Źródło: GUS (2014, 2015a). 
Table 4. The level of concentration of pig breeding in Poland and selected EU countries in 2010

Tabela 4. Poziom koncentracji chowu trzody chlewnej w Polsce i wybranych krajach UE w 2010 roku

\begin{tabular}{|c|c|c|c|c|c|}
\hline $\begin{array}{c}\text { Specification } \\
\text { Wyszczególnienie }\end{array}$ & $\begin{array}{l}\text { Polska } \\
\text { Poland }\end{array}$ & $\begin{array}{l}\text { Węgry } \\
\text { Hungary }\end{array}$ & $\begin{array}{l}\text { Niemcy } \\
\text { Germany }\end{array}$ & $\begin{array}{l}\text { Dania } \\
\text { Denmark }\end{array}$ & $\begin{array}{l}\text { Holandia } \\
\text { Netherlands }\end{array}$ \\
\hline $\begin{array}{l}\text { Number of farms with pigs (thous.) } \\
\text { Liczba gospodarstw z trzodą (tys.) }\end{array}$ & 388.5 & 183.1 & 60.1 & 5.1 & 7.0 \\
\hline $\begin{array}{l}\text { Number of pigs (thous.) } \\
\text { Liczba świń (tys.) }\end{array}$ & 15244.2 & 3207.9 & 27571.4 & 13173.1 & 12255 \\
\hline $\begin{array}{l}\text { Number of pigs on the farm (head) } \\
\text { Liczba świń w gospodarstwie (szt.) }\end{array}$ & 39.2 & 17.5 & 458.8 & 2583.0 & 1750.7 \\
\hline $\begin{array}{l}\text { Share of farms with 1-49 pigs (\%) } \\
\text { Udział gospodarstw z 1-49 świniami (\%) }\end{array}$ & 85.5 & 99.0 & 41.7 & 11.8 & 5.5 \\
\hline $\begin{array}{l}\text { Share of farms with 50-199 pigs (\%) } \\
\text { Udział gospodarstw z 50-199 świniami (\%) }\end{array}$ & 11.9 & 0.7 & 16.5 & 5.9 & 10.0 \\
\hline $\begin{array}{l}\text { Share of farms with more than } 200 \text { pigs (\%) } \\
\text { Udział gospodarstw z ponad } 200 \text { świniami (\%) }\end{array}$ & 2.6 & 0.3 & 41.7 & 82.3 & 84.3 \\
\hline $\begin{array}{l}\text { Share of pigs in herds of max. } 49 \text { head (\%) } \\
\text { Udział świń w stadach do } 49 \text { szt. (\%) }\end{array}$ & 25.6 & 22.1 & 1.0 & 0.1 & 0.03 \\
\hline $\begin{array}{l}\text { Share of pigs in herds of 50-199 head (\%) } \\
\text { Udział świń w stadach 50-199 szt. (\%) }\end{array}$ & 27.3 & 3.3 & 3.9 & 0.2 & 0.7 \\
\hline $\begin{array}{l}\text { Share of pigs in herds }>200 \text { head }(\%) \\
\text { Udział świń w stadach ponad } 200 \text { szt. (\%) }\end{array}$ & 47.1 & 74.6 & 95.1 & 99.7 & 99.3 \\
\hline
\end{tabular}

Source: Statistisches... (2013).

Źródło: Statistisches... (2013).

The scale of pig rearing in Poland in comparison to other countries, particularly leading producers of slaughter pigs, e.g. Germany, Denmark and Holland, is very low. Respective numbers are given in Table 4.

In 2010 the average size of pig herds in Poland was approx. 40 head. It was 2-fold greater than in Hungary, while it was as many as 65 times smaller than in Denmark, 45 times lower than in Holland and 12 times smaller than in Germany. It was the result of pig farm structure in Poland, where the share of farms with herds of max. 49 head was $85 \%$, while in Denmark and Holland it was 11.8 and $5.7 \%$, respectively. In turn, the share of farms keeping herds of min. 200 head in Poland was $2.6 \%$, whereas in Demark and Holland it was 82.4 and $85.7 \%$, respectively. The share of pig population in those farms in the above-mentioned countries was over $99 \%$, while in Poland it was only $47 \%$. These numbers indicate the huge disparity between Poland and the leading producers of slaughter pigs.

\section{PRODUCTIVITY OF POLISH PIG FARMS}

Table 5 presents numbers characterizing pig rearing on farms depending on their economic size, defined by the value of standard output (SO) expressed in thousand EUR. A total of 5 classes of economic size were distinguished: from the smallest with max. 8 thousand EUR SO to the largest with the range of 100-500 thousand EUR. A strong dependence of economic size on the area and scale of pig rearing expressed by the SD and on income from the farm. The correlation coefficient between these variables was over 0.9 . The income category, which is most informative on the efficiency of management, is income from management activity (the entrepreneur's profit). In the first three classes of economic size up to 50 thousand EUR SO the income from management is negative, which means that income from the farm did not cover costs of use of owned factors of production. In the first and second classes it did 
Table 5. Efficiency of Polish pig farms, depending on the economic size in 2009-2012

Tabela 5. Efektywność polskich gospodarstw trzodowych w zależności od wielkości ekonomicznej gospodarstw w latach 2009-2012

\begin{tabular}{|c|c|c|c|c|c|}
\hline \multirow{2}{*}{$\begin{array}{c}\text { Specification } \\
\text { Wyszczególnienie }\end{array}$} & \multicolumn{5}{|c|}{$\begin{array}{l}\text { Economic size of farms (thous. EUR SO) } \\
\text { Wielkość ekonomiczna gospodarstw (tys. euro SO) }\end{array}$} \\
\hline & $<8$ & $8-25$ & $25-50$ & $50-100$ & $100-500$ \\
\hline $\begin{array}{l}\text { UAA (ha) } \\
\text { Powierzchnia UR (ha) }\end{array}$ & 7.62 & 13.17 & 23.54 & 35.80 & 56.47 \\
\hline $\begin{array}{l}\text { Numbers of pigs (LU/farm) } \\
\text { Pogłowie trzody (SD/gospodar.) }\end{array}$ & 4.87 & 13.42 & 32.76 & 68.10 & 173.43 \\
\hline $\begin{array}{l}\text { Income from a farm (thous. PLN) } \\
\text { Dochód z gospodarstwa (tys. zl) }\end{array}$ & 9.29 & 25.07 & 56.02 & 105.97 & 222.98 \\
\hline $\begin{array}{l}\text { Cost of factors of production (thous. PLN) } \\
\text { Koszt włas. czyn. prod. (tys. zł) }\end{array}$ & 24.81 & 49.32 & 79.43 & 79.81 & 105.58 \\
\hline $\begin{array}{l}\text { Income from management (thous. PLN) } \\
\text { Dochód from management (tys. zł) }\end{array}$ & -15.52 & -24.25 & -24.31 & 26.13 & 117.40 \\
\hline $\begin{array}{l}\text { Income partity (\%) } \\
\text { Parytet dochodowy (\%) }\end{array}$ & 27.24 & 63.60 & 129.81 & 220.60 & 454.00 \\
\hline $\begin{array}{l}\text { Net investment rate (\%) } \\
\text { Stopa inwestycji netto (\%) }\end{array}$ & -78.01 & 0.00 & 0.25 & 50.26 & 78.00 \\
\hline $\begin{array}{l}\text { Share of payments in income (\%) } \\
\text { Udział płatności w dochodzie (\%) }\end{array}$ & 111.78 & 67.75 & 51.17 & 40.76 & 29.89 \\
\hline $\begin{array}{l}\text { Competitiveness index } W k 4 \\
\text { Wskaźnik konkurencyjności } W k 4\end{array}$ & 0.37 & 0.50 & 0.70 & 1.33 & 2.11 \\
\hline
\end{tabular}

Source: Polski FADN (n.d.).

Źródło: Polski FADN (b.d.).

not secure income at parity. In the third class $25-50$ thousand EUR SO was sufficient to cover costs of unpaid labour, but it was not sufficient to cover costs of use of owned land and capital. Also in farms of max. 50 thousand EUR SO the net investment rate was negative (up to 8 thousand EUR SO) or very low in the other two classes. The main source of income in these three classes of farm economic size was provided by all types of payments received by farmers. The development potential of analyzed farms is best illustrated by the competitiveness index. In the first three classes of economic size the competitiveness index $W k 2$ was below 1 , which means that income from the farm was lower than the costs of use of owned factors of production. Such farms have no development potential and are not competitive. In farms of class 4 with economic size of $50-100$ thousand EUR SO, using approx. 36 ha UAA and keeping a pig herd of $68 \mathrm{SD}$, the competitiveness index $W k 3$ was 1.33 , which indicates their capacity for development. They may not be considered competitive farms. Only farms of economic size of 100-500 thousand Euro SO using 56 ha UAA and keeping over 170 SD pigs may be considered competitive. The competitiveness index Wk4 in those farms was 2.11.

Tables 6 and 7 give figures characterising pig farms depending on the number of sows and sold fatteners in 2013. In both cases six classes of farms were distinguished. In terms of the number of kept sows the following classes were distinguished: 1-20 sows (class I) up to 80 sows and more (class VI) - Table 6. The class of max. 10 sows was rejected, since these farms had absolutely no chance for development. Income from management was negative in those farms. The population of farms in terms of the number of sold fatteners was also 
Table 6. Efficiency of Polish pig farms depending on the number of sows kept on farms in 2013

Tabela 6. Efektywność polskich gospodarstw trzodowych w zależności od liczby utrzymywanych loch w gospodarstwie w 2013 roku

\begin{tabular}{|c|c|c|c|c|c|c|}
\hline \multirow{2}{*}{$\begin{array}{c}\text { Specification } \\
\text { Wyszczególnienie }\end{array}$} & \multicolumn{6}{|c|}{$\begin{array}{l}\text { Number of sows on the farm } \\
\text { Liczba loch w gospodarstwie }\end{array}$} \\
\hline & $10-20$ & $20-30$ & $30-40$ & $40-50$ & $50-80$ & $>80$ \\
\hline $\begin{array}{l}\text { UAA (ha) } \\
\text { Powierzchnia UR ( ha) }\end{array}$ & 25.92 & 34.00 & 42.05 & 40.88 & 48.33 & 85.10 \\
\hline $\begin{array}{l}\text { Number of sows (head) } \\
\text { Liczba sows (szt.) }\end{array}$ & 14.06 & 24.50 & 34.72 & 43.99 & 61.41 & 147.85 \\
\hline $\begin{array}{l}\text { Number of reared piglets } \\
\text { Liczba odchowanych prosiąt }\end{array}$ & 18.09 & 17.48 & 18.25 & 18.47 & 19.41 & 20.46 \\
\hline $\begin{array}{l}\text { Sale of livestock (ton/farm) } \\
\text { Sprzedaż żywca (ton/gospodar.) }\end{array}$ & 28.71 & 46.35 & 65.52 & 83.31 & 119.49 & 287.58 \\
\hline $\begin{array}{l}\text { Sale price }(\mathrm{PLN} / \mathrm{kg}) \\
\text { Cena zbytu }(\mathrm{z} / \mathrm{kg})\end{array}$ & 5.23 & 5.40 & 5.46 & 5.47 & 5.64 & 5.59 \\
\hline $\begin{array}{l}\text { Income from a farm (PLN thous.) } \\
\text { Dochód z gospodarstwa (tys. zł) }\end{array}$ & 61.49 & 100.90 & 144.04 & 155.05 & 227.49 & 562.78 \\
\hline $\begin{array}{l}\text { Cost of owned factors of production (PLN thous.) } \\
\text { Koszt własny czynników produkcji (tys. zł) }\end{array}$ & 74.42 & 86.15 & 93.15 & 99.72 & 111.49 & 155.65 \\
\hline $\begin{array}{l}\text { Income from management (PLN thous.) } \\
\text { Dochód z zarządzania (tys. zł) }\end{array}$ & -12.93 & 14.75 & 50.89 & 55.33 & 116.00 & 407.13 \\
\hline $\begin{array}{l}\text { Share of payments in income (\%) } \\
\text { Udział płatności w dochodzie (\%) }\end{array}$ & 52.98 & 41.12 & 36.32 & 38.61 & 26.48 & 18.25 \\
\hline $\begin{array}{l}\text { Competitiveness index } W k 4 \\
\text { Wskaźnik konkurencyjności } W k 4\end{array}$ & 0.83 & 1.17 & 1.55 & 1.55 & 2.04 & 3.61 \\
\hline
\end{tabular}

Source: Polski FADN (n.d.), 2014.

Źródło: Polski FADN (b.d.), 2014.

divided into six classes: from 80-120 to 1000 and more sold fatteners (Table 7).

The class of max. 80 sold fatteners was rejected, as it had no development potential. The analysis of figures in Tables 6 and 7 leads to the following statements:

- there is a close relationship between the scale of rearing defined by the number of kept sows and sold fatteners and financial results of farms - income from the farm, income from management and competitiveness potential

- rearing efficiency defined by the number of reared piglets per sow in a year increased with the increase in the scale of rearing. The difference between extreme classes was 13 and $17 \%$, respectively
- sale prices of slaughter pigs increased with an increase in scale. The difference between extreme classes was 7 and $16 \%$, respectively

- income from management in farms keeping max. 20 sows or selling max. 400 fatteners was negative

- farms keeping max. 20 sows or selling max. 400 fatteners had no chance for development

- farms keeping from 20 to 50 sows and selling from 400 to 1000 fatteners had development potential

- farms keeping min. 50 sows and selling min. 1000 fatteners annually may be considered fully competitive. The weakest link in pig rearing in Poland is connected with the production of piglets, as evidenced by the growing imports of piglets. Table 8 presents figures 
Ziętara, W. (2016). Condition and development opportunities of breeding pigs in Poland. J. Agribus. Rural Dev., 4(42), 687-701. DOI: 10.17306/JARD.2016.95

Table 7. Efficiency of Polish pig farms, depending on the number of sold fatteners in 2013

Tabela 7. Efektywność polskich gospodarstw trzodowych w zależności od liczby sprzedanych tuczników w 2013 roku

\begin{tabular}{|c|c|c|c|c|c|c|}
\hline \multirow{2}{*}{$\begin{array}{c}\text { Specification } \\
\text { Wyszczególnienie }\end{array}$} & \multicolumn{6}{|c|}{$\begin{array}{l}\text { Number of sold fatteners } \\
\text { Liczba sprzedanych tuczników }\end{array}$} \\
\hline & $80-120$ & $120-200$ & $200-400$ & $400-700$ & $700-1000$ & $\geq 1000$ \\
\hline $\begin{array}{l}\text { UAA (ha) } \\
\text { Powierzchnia UR (ha) }\end{array}$ & 14.98 & 20.00 & 28.74 & 34.27 & 45.42 & 60.80 \\
\hline $\begin{array}{l}\text { Number of sows (head) } \\
\text { Liczba sows (szt.) }\end{array}$ & 5.89 & 8.75 & 15.12 & 25.31 & 32.87 & 60.40 \\
\hline $\begin{array}{l}\text { Number of reared piglets } \\
\text { Liczba odchowanych prosiąt }\end{array}$ & 17.49 & 16.83 & 17.06 & 17.72 & 19.20 & 20.45 \\
\hline $\begin{array}{l}\text { Sale of livestock (ton/farm) } \\
\text { Sprzedaż żywca (ton/gospodar.) }\end{array}$ & 11.59 & 18.51 & 32.49 & 59.26 & 93.23 & 259.00 \\
\hline $\begin{array}{l}\text { Sale price }(\mathrm{PLN} / \mathrm{kg}) \\
\text { Cena zbytu }(\mathrm{z} / \mathrm{kg})\end{array}$ & 4.97 & 5.15 & 5.31 & 5.45 & 5.63 & 5.76 \\
\hline $\begin{array}{l}\text { Income from a farm (PLN thous.) } \\
\text { Dochód z gospodarstwa (tys. zł) }\end{array}$ & 23.97 & 38.26 & 65.31 & 111.25 & 166.27 & 336.73 \\
\hline $\begin{array}{l}\text { Cost of owned factors of production (PLN thous.) } \\
\text { Koszt własny czynników produkcji (tys. zł) }\end{array}$ & 60.69 & 66.17 & 77.51 & 87.40 & 98.94 & 96.07 \\
\hline $\begin{array}{l}\text { Income from management (PLN thous.) } \\
\text { Dochód z zarządzania (tys. zł) }\end{array}$ & -36.72 & -27.91 & -12.20 & 23.85 & 67.33 & 240.66 \\
\hline $\begin{array}{l}\text { Share of payments in income (\%) } \\
\text { Udział płatności w dochodzie (\%) }\end{array}$ & 76.21 & 65.07 & 56.91 & 36.34 & 34.26 & 21.46 \\
\hline $\begin{array}{l}\text { Competitiveness index } W k 4 \\
\text { Wskaźnik konkurencyjności } W k 4\end{array}$ & 0.39 & 0.58 & 0.84 & 1.27 & 1.68 & 3.50 \\
\hline
\end{tabular}

Source: Polski FADN (n.d.), 2014.

Źródło: Polski FADN (b.d.), 2014.

Table 8. Efficiency of Polish pig farms, depending on the number of piglets sold in 2013

Tabela 8. Efektywność polskich gospodarstw trzodowych w zależności od liczby sprzedanych prosiąt w 2013 roku

\begin{tabular}{|c|c|c|c|}
\hline \multirow{2}{*}{$\begin{array}{c}\text { Specification } \\
\text { Wyszczególnienie }\end{array}$} & \multicolumn{3}{|c|}{ Number of sold piglets - Liczba sprzedanych prosiąt } \\
\hline & $<200$ & $200-500$ & $500-1200$ \\
\hline 1 & 2 & 3 & 4 \\
\hline $\begin{array}{l}\text { UAA (ha) } \\
\text { Powierzchnia UR (ha) }\end{array}$ & 9.26 & 15.93 & 20.28 \\
\hline $\begin{array}{l}\text { Number of sows (head) } \\
\text { Liczba sows (szt.) }\end{array}$ & 6.99 & 19.14 & 43.58 \\
\hline $\begin{array}{l}\text { Number of reared piglets } \\
\text { Liczba odchowanych prosiąt }\end{array}$ & 18.71 & 18.15 & 20.24 \\
\hline $\begin{array}{l}\text { Sale of livestock (t/farm) } \\
\text { Sprzedaż żywca (t/gospodar.) }\end{array}$ & 2.68 & 6.76 & 17.70 \\
\hline
\end{tabular}


Table 8 cont. - Tabela 8 cd.

\begin{tabular}{|c|c|c|c|}
\hline 1 & 2 & 3 & 4 \\
\hline $\begin{array}{l}\text { Sale price }(\mathrm{PLN} / \mathrm{kg}) \\
\text { Cena zbytu }(\mathrm{zt} / \mathrm{kg})\end{array}$ & 8.40 & 8.50 & 8.36 \\
\hline $\begin{array}{l}\text { Income from a farm (PLN thous.) } \\
\text { Dochód z gospodarstwa (tys. zł) }\end{array}$ & 12.00 & 42.50 & 84.54 \\
\hline $\begin{array}{l}\text { Cost of owned factors of production (PLN thous.) } \\
\text { Koszt własny czynników produkcji (tys. zł) }\end{array}$ & 49.24 & 65.53 & 70.09 \\
\hline $\begin{array}{l}\text { Income from management (PLN thous.) } \\
\text { Dochód z zarządzania (tys. zł) }\end{array}$ & -37.21 & -23.03 & 14.45 \\
\hline $\begin{array}{l}\text { Share of payments in income }(\%) \\
\text { Udział płatności w dochodzie (\%) }\end{array}$ & 91.20 & 48.84 & 32.85 \\
\hline $\begin{array}{l}\text { Competitiveness index } W k 4 \\
\text { Wskaźnik konkurencyjności } W k 4\end{array}$ & 0.24 & 0.65 & 1.21 \\
\hline
\end{tabular}

Source: Polski FADN (n.d.), 2014.

Źródło: Polski FADN (b.d.), 2014.

characterizing farms specializing in rearing and sale of piglets. Available data made it possible to distinguish only 3 classes: max. $200 ; 200-500$ and $500-1200$ sold piglets. Figures given in Table 8 confirm earlier reports on the relationship between the scale of rearing and productivity and economic results of farms. No potential for development is found in farms keeping max. 20 sows and selling max. 500 piglets annually. A negative income from farms and the competitiveness index below 1 are reported there. Chances for development are found for farms selling from 500 to 1200 piglets annually and keeping over 40 sows. The competitiveness index $W k 3$ in those farms is 1.21. Farms selling over 1200 piglets and keeping minimum 60 sows may be considered competitive.

\section{POTENTIAL SUPPORT FOR FARMS SPECIALIZING IN PIGLET REARING AND SALE WITHIN RDP IN 2014-2020}

In view of the fact that rearing piglets is the weakest link in the production of slaughter pigs the Ministry of Agriculture and Rural Development (MRiRW) implemented the programme of financial support for farms undertaking "production of piglets", issuing a respective regulation". Within the operation "Modernization

\footnotetext{
${ }^{5}$ Regulation of the Minister of Agriculture and Rural Development of 21 August 2015 on specific conditions and mode of
}

of farms" and the subaction "Support for investments in farms", area A "Development of piglet production" was identified. For this area the financial subsidy of 102 million EUR was allocated. At the same time it is estimated that between 500 and 2000 farms should be granted this subsidy. In accordance with the abovementioned regulation this form of financial assistance may be allocated to:

- farms belonging to physical persons (farmers - owners of individual holdings) and legal persons as well as producer groups

- minimum economic size of farms should be 10 thousand EUR SO, while maximum economic size should not exceed 200 thousand EUR SO

- in the case when the operation is to be performed by two beneficiaries, the total amount should be min. 15 thousand EUR, in a situation when the economic size of a farm owned by one beneficiary is max. 10 thousand EUR

- as a result of the programme implementation the number of sows will be min. 50 head.

allocation and direct payments to operations such as "Modernization of farms" within the subaction "Support for investments in farms" included in the Rural Development Programme in the years 2014-2020. 
The maximum level of support for piglet production is 900 thousand PLN per 1 applicant. In the case when financial support is allocated to one applicant $50 \%$ costs eligible costs are reimbursed, while it is $60 \%$ in the case of an operation realized by joint applicants or a young farmer. Eligible costs in this subaction include:

- costs of construction, reconstruction, repair connected with modernization of buildings or structures used for agricultural production purposes, including preparation for sale of agricultural produce from that farm

- purchase or concluded leasing contracts with the transfer of ownership rights for new machines, equipment, installations for agricultural production, including preparation for sale of agricultural produce from that farm.

The decision to grant financial support is based on the score of points given considering the following criteria:

- increasing the herd of sows as a result of the realization of the operation. The farm receives 1 point when the herd is increased by 10 to 20 sows. For each additional increase in herd size by 10 sows the farm is given 1 point. The maximum score is 5 points, when the herd size is increased by more than 50 sows

- when as a result of the operation the mean herd size is from 100 to 200 sows, the farm receives 1 point, when it is by 200 to 300 sows it receives 2 points, while when reaching the average size of min. 300 sows it receives 3 points

- when the applicant is a young farmer (aged max. 40 years) 3 points are given

- if investments are environmentally friendly or prevent adverse effects of climate change the farm may receive max. 5 points ${ }^{6}$

- the applicants - piglet producers from the Kujawskopomorskie voivodeship receive 1 point and additionally 1 extra point, when the applicant is a member of a producer group.

The first application round and evaluation of these applications took place in the second half of 2015. A total of 2471 farmers filed their applications within the

\footnotetext{
${ }^{6}$ Equipment and building types register, along with its environment-friendly assessment, is included in the appendix to the before mentioned Regulation of the Ministry of Agriculture and Rural Development.
}

"Modernization of farms" subaction. The largest number, i.e. 1529 applications, concerned investments connected with development of milk production, and 645 applications - with development of beef cattle production. The smallest number, i.e. only 297 applications, were connected with development of piglet production. A significant cause for the small number of applications for support of investments connected with piglet production is related with problems to obtain permits for the construction of piggeries due to environmental conditions and social conflicts (a lack of the noxious odour act and complicated beaurocratic procedures) (Dyba et al., 2016). In this and the next years application procedures will take place by the end of March.

A factor promoting development of pig rearing according to T. Blicharski is the Regulation of the European Parliament and Council (EU) 1308/2013 specifying in its art. 168 the obligation to incorporate prices and payment conditions in the contracts for the purchase of slaughter pigs by meat processing plants. This Regulation also stipulates the opportunity to establish a Private Insurance Fund (Blicharski, 2014). These solutions should strengthen the bargaining position of producers of slaughter pigs in relation to their contractors. However, it needs to be stressed that professional processors (meat processing plants) are interested in concluding contracts with producers with a greater scale of production. Thus producers with a large scale of production have a chance for development.

\section{CONCLUDING REMARKS}

Conducted studies provide grounds for the following statements and conclusions:

- the drastic decline in the population of pigs in Poland, observed after 2007, affected farms with a smaller scale of animal production, keeping herds of max. 200 head

- the rate of concentration of pig rearing on Polish farms is very low in comparison with the leading producers of slaughter pigs, e.g. Germany, Denmark and Holland. In 2010 on average Polish farms kept herds of 40 head, while in the above-mentioned countries it was 460, 2583 and 1751 head, respectively

- the regional diversification in the pig population increased in the investigated period. In 1990 54\% pig population were kept in the five leading voivodeships, whereas in 2014 it was $72 \%$ total population. 
The leading voivodeships in pig production include the Wielkopolskie and Kujawsko-pomorskie, in which in 2014 46.6\% all pigs were kept. A drastically low level of pig population was found in the voivodeships of southern Poland: the Małopolskie, Podkarpackie and the Świętokrzyskie

- farms keeping max. 20 sows and selling max. 400 fatteners annually had no chances for development. Such a chance was found for farms keeping 20-50 sows and selling from 400 to 1000 fatteners or selling from 500 to 1200 piglets and porkers

- farms keeping min. 50 sows and selling over 1000 fatteners annually or over 1200 piglets and porkers may be considered fully competitive

- conducted analyses confirmed the adopted research hypothesis assuming that "The primary factor determining efficiency of production of slaughter pigs is connected with the scale of its production"

- introduction of support for piglet production within the Rural Development Programme 2014-2020 within the operation "Modernisation of farms" needs to be considered a positive solution; however, its effects may be undermined by problems with receiving permits for the construction of piggeries.

\section{REFERENCES}

Analizy rynkowe (2011). Handel zagraniczny produktami rolno-spożywczymi - stan i perspektywy, nr 34. Warszawa: IERiGŻ-PIB.

Analizy rynkowe (2015a). Handel zagraniczny produktami rolno-spożywczymi - stan i perspektywy, nr 42. Warszawa: IERiGŻ-PIB.

Analizy rynkowe (2015b). Rynek mięsa - stan i perspektywy, nr 49. Warszawa: IERiGŻ-PIB.

Biswanger, H. Ch. (2011). Spirala wzrostu, pieniądz, energia i kreatywność w dynamice procesów rynkowych. Poznań: Zysk i S-ka.

Blicharski, T. (2014). Aktualny stan produkcji żywca wieprzowego w Polsce i najbliższe perspektywy. POLSUS nr 17, Warszawa.

Blicharski, T., Hammermeister, A. (Eds.). (2013). Strategia odbudowy i rozwoju produkcji trzody chlewnej w Polsce do 2030 r. Warszawa: Polski Związek Hodowców i producentów Trzody Chlewnej.

Dyba, I., Chmielewski, Ł., Głuchowski, Ł., Wojtaszczyk, B. (2016). Rolnicy idą po modernizację. Retrieved from: Farmer.pl.
Goraj, L., Bocian, M., Osuch, D., Smolik, A. (2015). Parametry techniczno-ekonomiczne według grup gospodarstw rolnych uczestniczących w polskim FADN w 2013 r. IERiGŻ-PIB.

GUS (1996-2015). Rocznik Statystyczny Rolnictwa. Warszawa: Główny Urząd Statystyczny.

GUS (2011). Powszechny Spis Rolny 2010. Raport z badań. Warszawa: Główny Urząd Statystyczny.

GUS (2015a). Mały Rocznik Statystyczny. Warszawa: Główny Urząd Statystyczny.

GUS (2015b). Rolnictwo w 2014 r. Warszawa: Główny Urząd Statystyczny.

Józwiak, W. (2009). Zdolność konkurencyjna polskich gospodarstw rolnych $\mathrm{w}$ zestawieniu $\mathrm{z}$ gospodarstwami węgierskimi i niemieckimi. In: W. Józwiak (Ed.), Sytuacja ekonomiczna, efektywność funkcjonowania i konkurencyjność polskich gospodarstw rolnych osób fizycznych. Warszawa: IERiGŻ-PIB.

Kleinhanss, W. (2015). Konkurencyjność głównych typów gospodarstw rolniczych w Niemczech. Zagad. Ekon. Roln., 1(342), 25-41.

Mirkowska, Z., Ziętara, W. (2015). Sytuacja ekonomiczna i efektywność polskich gospodarstw trzodowych. Zagad. Ekon. Roln., 1(342), 42-56.

Polski FADN (n.d.). http://fadn.pl/

Rozporządzenie Ministra Rolnictwa i Rozwoju Wsi z dnia 21 sierpnia 2015 r. w sprawie szczegółowych warunków i trybu przyznawania oraz wypłaty pomocy finansowej na operacje typu „Modernizacja gospodarstw rolnych” w ramach poddziałania „Wsparcie inwestycji w gospodarstwach rolnych" objętego Programem Rozwoju Obszarów Wiejskich na lata 2014-2020.

Stankiewicz, M. J. (2003). Konkurencyjność przedsiębiorstwa. In: Źródła przewag konkurencyjnych przedsiębiorstw w agrobiznesie. Lublin: Wyd. AR w Lublinie.

Statistisches Jahrbuch über Ernährung, Landwirtschaft und Forsten 2012 (2013). Retrieved from: http://www.bmel. de/SharedDocs/Pressemitteilungen/2013/046-StatistischesJahrbuch2012.html?nn=312878.

Świtalski, W. (2005). Innowacyjność i konkurencyjność. Warszawa: Wyd. Uniwersytetu Warszawskiego.

Woś, A. (2003). Konkurencyjność potencjalna polskiego rolnictwa. In: Źródła przewag konkurencyjnych przedsiębiorstw w agrobiznesie. Lublin: Wyd. AR w Lublinie.

Ziętara, W., Zieliński, M. (2012). Efektywność i konkurencyjność polskich gospodarstw rolniczych nastawionych na produkcję roślinną. Zagad. Ekon. Roln., 1, 40-62. 


\section{STAN I MOŻLIWOŚCI ROZWOJU CHOWU TRZODY CHLEWNEJ W POLSCE}

Streszczenie. W artykule przedstawiono aktualny stan pogłowia trzody chlewnej w Polsce i przyczyny jego spadku w ostatnich kilkunastu latach. Za główną przyczynę tego stanu należy uznać obniżenie opłacalności produkcji żywca wieprzowego, szczególnie w gospodarstwach o małej skali produkcji. Zasadniczy spadek pogłowia trzody chlewnej wystąpił w gospodarstwach utrzymujących stada do 200 sztuk. Szans rozwojowych pozbawione są gospodarstwa utrzymujące do 20 loch lub sprzedających do 400 tuczników rocznie. Szanse rozwojowe posiadają gospodarstwa utrzymujące 20-50 loch lub sprzedające rocznie 400-1000 tuczników lub 500-1200 prosiąt. W pełni konkurencyjne są gospodarstwa utrzymujące powyżej 50 loch i sprzedające powyżej 1000 tuczników rocznie, względnie powyżej 1200 prosiąt. Podstawowym czynnikiem decydującym o opłacalności produkcji żywca wieprzowego jest jego skala.

Słowa kluczowe: pogłowie trzody chlewnej, gospodarstwa trzodowe, efektywność produkcji, konkurencyjność 